\title{
SOME ASPECTS OF ENSURING SOCIO-CULTURAL COMPETENCE OF THE STUDENT IN THE CONTENT OF LATVIAN LANGUAGE
}

\section{Summary}

\section{Introduction}

The more changeable social circumstances are, the more important is the responsibility of the teacher to help each student understand his/her specific identity. It is vitally important to realize and fulfil the learners' social role in the particular cultural environment.

\section{Aim of the Study}

To analyze a number of content aspects of the Latvian language as a subject in order to provide the socio-cultural competence of student and to indicate pedagogical tools used to improve it.

\section{Materials and Methods}

The theoretical method - the study and analysis of scientific literature.

\section{Results}

The folklore and the semantic aspect of the Latvian language in the context of providing the sociocultural competence are assessed in the educational provisions, study programmes and the Latvian language educational tools.

\section{Conclusions}

In order to prepare teachers for higher educational establishments it is necessary to include study subjects that would allow future teachers to gain theoretical and practical experience about the traditional culture and to master the proper methodology for learning the traditional culture, working with student not only in the Latvian language studies, but also in other study subjects in the elementary school.

Key words: content of Latvian study, folklore, the semantic aspect of a language, traditional culture, socio-cultural competence, identity.

\section{Introduction}

Tendencies of globalisation bring forward the issue of significance of traditional cultures of various ethnoses in an international scope, the necessity to acquire cultural values and type of acquisition in the pedagogical process. During the previous years, Latvian regulatory enactments for education, education programs mainly focus on bilingual learning as means for ensuring the acquisition of languages and various ethnical cultures. Such important issue as ensuring a good quality acquisition of traditional culture heritage of the Latvian ethnos during the learning process has been tackled less. This exactly has an undeniably significant meaning for formation of each individual's cultural identity and feeling of belonging to the State of Latvia, for development of socio-cultural competency.

Influence of the western culture (pop-culture) nowadays changes attitude towards values, viewpoints and traditions. A reorientation of values takes place; therefore one of principal tasks for today's education process is to facilitate student's interest in his own ethnical culture and to simultaneously help understand its place in environment of other cultures. 
Ethnical identity and culture traditions representing this identity are not a quality awarded to the nation in a ready-made and unchanged manner. These are chosen, formed during communication activities and confirmed, recreated anew. They represent and compete with other nation identities and their symbols (Bula, 2000).

The language most widely accumulate and express the cultural identity, an ethnos' experience, as well as preserve and forward the genetic memory of the ethnos. During the Latvian language studies, a text, sentence, word can be seen not only in a grammatical but also in a cultural aspect. In order to give the student a possibility to get better acquainted with the world, where he lives, to form understanding of the fact that each ethnos has its own view of the world, its own ways, traditions which are reflected in the language, that the culture of various ethnoses has similar and different traits, that tolerant attitude should be cultivated towards otherness, the contents of basic education of the Latvian language should focus on the socio-cultural competency (Learning process: Latvian, 2004).

By cultivating socio-culture competency during the Latvian language studies, the student perceives the language not only as a source for intellectual heritage of his own ethnos but also for cognition of other ethnoses' culture, ways, and traditions.

Learning of ethnic and general human culture values stimulates true mutual understanding and helps overcome various ethnic prejudices. Culture should be regarded as means of selfidentification and learning of others and their identification. In the time when borders between countries, nations and nationalities is rapidly disappearing, when the world experiences the socalled hybridization process of culture merging, the role of culture traditions and language for strengthening and preserving ethnos' identity turns into the most significant aspect of students' learning and upbringing process (Konsa, 2004; Anspoka, Siliņa-Jasjukeviša, 2006).

\section{Aim of the Study}

To analyse some aspects of contents of the Latvian language as a study subject for development of students' socio-cultural competency and to emphasise pedagogical tools which should be used for its improvement.

\section{Materials and Methods}

The study analyses scientific literature, state and international regulatory enactments on formation of identity of an individual and ethnos and importance of culture acquisition during the pedagogical process. Quality of folklore texts and reflection of the semantic aspect of the language in learning means provided for the Latvian language studies during the first phase of elementary education (classes 1 - 4) was studied.

Acquisition of the ethnic culture creates positive circumstances for development of each individual's personality, life-long career formation and thus facilitates sustainable development of multicultural society.

In the 21 st century, the ethnical culture is the main precondition for attesting the identity and existence of each nation, especially the smaller one.

Likewise the Latvian cultural politics emphasises the ethnical identities and principle of safeguarding the cultural heritage. Main tasks of the cultural politics for strengthening the ethnic identity and cultural values are to improve the safeguarding, protection, study and availability of Latvian cultural heritage, paying special attention to educating the society on the role of the cultural heritage for sustainable development of the state. For implementation of this process in cooperation with the Ministry of Education and Science during the general education process, development and implementation of an educational program on cultural heritage is supported (State Guidelines for Cultural Politics for years 2006-2015, 37). 
One of main tasks of the elementary education program is to "form a concept on Latvian, European and global cultural heritage" (Regulations of the Cabinet of Ministers regarding state standards in elementary education and standards of subjects in elementary education (Cabinet of Ministers Regulations No 1027 as of 19.12.2006).

Acquisition of cultural heritage is included in the content of first stage subjects of elementary education program - languages, Maths and Technologies, Arts, Man and Society. As a result of learning and upbringing, the student can acquire a set of knowledge, skills and attitudes which he needs for self-assertion in multicultural society.

The field of languages includes the Latvian language. One of tasks for the Latvian language studies is development of the student's socio-cultural competency because it is important to acquire "the language as a component of the nation's culture and means for cognition, the language as means for preservation and development of the personality and ethnic identity." (State Standard of Elementary Education. The Latvian language for classes 1 - 9, 2006).

Taking into account that nowadays the process of continuation of the traditional culture in its natural environment - family - is almost non-existent, this function is mainly performed by educational institution and teachers working there. Thus the problems on how to grant a sufficient space for the Latvian language as a subject, how to help the student to acquire the traditional cultural values during the learning process so that they become his values in the whole life, becomes much more topical.

The aforementioned problems have become especially important since 16 December, 2004, when the law on UNESCO Convention on Safeguarding and Development of Intangible Cultural Heritage, stipulating that the Latvian educational system should undertake liability for implementation of the Convention requirements in a qualitative manner.

The Convention defines the intangible cultural heritage as "practices, representations, expressions, knowledge, skills - as well as the instruments, objects, artefacts and cultural spaces associated therewith - that communities, groups and, in some cases, individuals recognize as part of their cultural heritage. This intangible cultural heritage, transmitted from generation to generation, is constantly recreated by communities and groups in response to their environment, their interaction with nature and their history, and provides them with a sense of identity and continuity, thus promoting respect for cultural diversity and human creativity" (UNESCO Convention for the Safeguarding of Intangible Cultural Heritage, 2006).

The adopted law confers a high importance to the issue on research work in the field of traditional culture pedagogy, on development of methodology for acquisition of the traditional culture by various age groups of children, which would be scientifically grounded. International conventions in the field of culture, which Latvia has joined, bring forward the obligation to take care of the ethnical culture not only due to self-awareness but also due to safeguarding of universal cultural heritage (UNESCO Universal Declaration on Cultural Diversity, 2001).

The range of teaching aids approved by the Ministry of Education and Science is wide, the teacher has the possibility to choose and work with such teaching literature, which in his opinion is most suitable for the standard requirements of the State elementary education, which complies with the needs of students in the definite class, for the implementation of the development program and allows to help the student to acquire the contents of the subject most successfully.

In order to evaluate the reflection of learning contents expected for acquisition of the Latvian traditional culture in teaching tools for the Latvian language, several sets of teaching aids for the Latvian language in classes 1 - 4 were analysed: Ā. Ptičkina, Zīle (publishing house Zvaigzne ABC), 
Z. Anspoka, Rudens. Ziema. Pavasaris (publishing house Lielvārds), a set of teaching aids made by group of authors for integrated studies Ar gudru ziņu (publishing house RaKa).

Although the teaching aids published during the most recent years offer folklore fragments covering all annual events, although the concept can be perceived on all traditional annual celebrations including winter and spring solstice, which were a taboo in the so-called Soviet period (Meistere, 2000), still the mentioned teaching aids do not represent a large amount of included folklore units (folk songs, tales and others). Upon evaluating the quality of folklore materials included in the teaching aids, it is apparent that sometimes these provide fragmentary introduction to ethnical traditions.

The interpretation of contents of the annual celebrations - winter and spring solstices offered by the authors of the teaching aids should be evaluated critically within the aspect of traditional culture. Sometimes the authors of books concentrate attention on stressing secondary, more recent phenomena of culture. The themes for the time around spring solstice have the character of a rabbit variously interpreted; likewise gnomes are active in almost all annual events.

It should be noted that the rabbit as a mythological character with a specific symbolic meaning is more widely known in Germanic mythology and is being focussed on in modern subculture of supermarkets. By turning an excessive attention to manifold reflection of this character in the spring solstice texts meant for the first phase of elementary education, the understanding of the meaning of contents included in the traditional annual celebrations is endangered. Information on significance, time of celebration and context for the Lielā diena (spring solstice) in teaching aids is reflected in historical discourse or stressing only the entertaining function of the celebration. Similar note refers to the gnome character being extremely emphasised in the contents of the teaching aids because it has little to do with Latvian traditional culture.

In the teaching aid Ar gudru ziņu for class 4 provided for the Latvian language studies, on page 151 in part 2 has a story "Saulgriežu nakts" (Solstice Night) by Signe Krasnova included, where the main characters trolls (!) (There is no such a character in the Latvian folklore) try to reveal the essence of summer solstice in a conversation.

When including beliefs, riddles and others, the authors of the teaching aids have ignored information on local source of the offered samples without indicating their place of origin and the narrator. Such information could rouse the student's interest and wish to find out the region's cultural traditions and would facilitate the concept on formation and development of traditions (Anspoka, Siliņa-Jasjukeviča, 2006).

The fairy-tales (brīnumpasakas), tales (teikas), legends (nostāsti), short folklore (proverbs, sayings, riddles) and folk songs reflect the general understanding of ethnical traditions in somewhat selective manner.

Relating folk songs to seasons has created some problems for the authors of books. Without connection to human life and thus the related everyday and celebration traditions, there are no such folk songs, therefore "folk songs" composed by the authors of books themselves appear in the teaching tools, and they cannot be regarded as a sample of good quality for understanding of the classical folk song. Quite often these compositions are so much "improved" that the semantic structure of folk songs is destroyed. "Form of the folk song is as important as its contents, to say in other words, the form was that secret, from-others-hidden little chamber, the lack of whose knowledge denied the understanding of the deep meaning of the narrated message. The form was a code of communication (of one household, tribe, tribal community and the like)." (Kursite, 1996, 139).

Also the methodological expressions of the authors of books should be equally seriously 
evaluated, since they invite the students to "play" with the folklore text, change it voluntarily, replace, compose their own variants and the like. It should be agreed that folk songs may have many variants recorded in the sources, which though different have emerged within the frame of tradition. Their internal structure, core and message have remained unchanged.

It should be taken into account that nowadays most students have no experience of usage of the folklore texts because contact with the folklore text is only during the pedagogical process. Thus only after an episodic training during the learning process the student cannot compose his own variant of the text, which would comply with those criteria being characteristic of the tradition by using the folk song's metrics, stylistics, symbols and the like. Using such methods, the student's attitude towards the folklore text may become superficial and careless. Skills to use the text in compliance with the cultural traditions should be realised in a purposefully managed pedagogical process by acquiring the specifics of the language and form of the culture, learning to see the variety of the ethnical culture.

A significant problem in the teaching aids is interpretation of word semantics. The offered samples lack attention drawn to revelation of symbolic meaning. Likewise the methodological indications do not contain commentaries useful for pedagogical work. Folklore samples, especially folk songs, during the Latvian language studies have become an exercise for reading skills, mechanical memory and expressive speech.

"In ritual songs for engagement and wedding, which tell of marriage, quite often bride and the groom are not called by their real names but called by the totemic code of birds or animals. Most typical and most frequently used symbolical pair in the engagement ritual of Latvian folk songs is hawk and partridge, wagtail, hen, golden-eye, tit, snow bunting, woodcock. In the mentioned pair, the hawk is a symbolic designation of a male, suitor in the totemic code of birds, but the partridge, wagtail, hen, golden-eye, tit, snow bunting, and woodcock are the totemic symbols of the female, bride. The hawk as a bird "from above" embodies a hunter, force, speed, cruelty, active beginning, is opposed to land birds which embody passivity: the partridge, hen, golden-eye, wagtail, snow bunting, woodcock, whose natural habitat related to the earth, field, waters. In the mythical thinking, the hawk by symbolising the above, the world of male deities, is opposed to the below, the classifiers of the earth and matricentric deities - land or water birds. Within the mythical thinking, the birds are not only the classifiers of cosmic zones, but also symbols of social structures, which are directly approved by view on birds for pre-ancestors and totems of tribes." (Ozolinšs, 2006, 12).

Since the approach that themes oriented to culturology are reviewed in unrelated manner within the content of different subjects (most often it takes place in the native language, Social Sciences, Music lessons) is dominating in the issue of acquisition of the traditional culture in Latvia, then development of socio-cultural competency lack system, context, the folklore text is used as learning task whose primary aim is not to reveal some phenomenon of the traditional culture, but to improve the student's experience of language activity. Often, the folk songs in the contents of the Latvian language studies appear in exercises related to improvement of reading ability, acquisition of language rules, for example, Read the folk song! Find and read, which words should always be written with a capitalised first letter! Write down the folk song! Write down neatly the rhyme! Learn one folk song by heart! The folk song as a song to be sung in a specific situation with a certain purpose goes to the background. Most often the students have to learn them by heart and recite them for the teacher in front of the classroom, sometimes without understanding the meaning because the lexis of the folk song is not clear for a modern student without a purposefully planned work. Such methodology does not ensure sufficiently deep understanding of the student on traditions of 
the ethnic culture, wish to get insight in fragments included in the teaching aids on traditions of traditional culture, ways and others, quite opposite - it provokes resistance.

In the teaching tools of the Latvian language, mostly short stories and poems can be found. Likewise the primitive content of these texts helps the student only partially to understand the essence of the Latvian and other ethnoses' culture and provoke inner feeling.

\section{Results and Discussion}

The learning content provided for the Latvian language studies cannot be focussed only to acquisition of listening, talking, reading and writing skills. This facilitates the student's associative thinking, understanding of values and acquisition of traditions of the ethnic culture. An outstanding professional need is to see the content of the Latvian language as a study in its whole manifold interconnection. The study content is characterised by the cultural-historic context, which includes information on ethnic values, skills to use the acquired information in communication situations and attitude towards the ethnos' traditional culture as value in itself and in multicultural society.

Since the socio-cultural competency is characterised also by the ability to perceive the information included in a word as the basic unit of the language, in a sentence and text regarding ethnos' view of the world, its traditions, practices, their differences and similarities in various regions, in cultures in various ethnoses, then in semantic relation to the learning content of the Latvian language, the attention should be paid to purposefully planned activity with the folklore texts and fiction, so that the student has the possibility first to discover himself the content expressed in phraseologisms, place-names, local words, related words and various grammatical forms at a practical activity, and only then to see also the regularity to be observed at literary pronunciation and orthography.

The folklore texts within the content of the Latvian language studies reveal functional character of the folklore, its relation to the real life, students can learn the skill to use the folklore as a significant part of their lives (celebrating annual events, acquiring the folklore of the region, traditions, practices, history and the like), as well as learn mutual cooperation and thus acquire the experience of social activity.

As the observed phenomena at practice witness, most often the teacher's personal interest, pedagogical proficiency, enthusiasm and understanding of folklore teaching/learning determines the quality of student's acquisition of the traditional cultural heritage and whether this introduction becomes significant for him. The process of inheritance and renovation of traditions takes place under the guidance of a professional teacher, students are those who continue the interrupted process of inheritance of the traditional culture and carry away also their parents with these ideas. As a result, the students' parents are involved in acquisition of the traditional culture, and this newly discovered experience serves as a factor which unites and strengthens the family, providing a simultaneous vitality to the cultural values (Оленкин, 2005; Konsa, 2004).

Most suitable model for acquiring the traditional culture within the pedagogical process is mutually enriching cooperation between students $\leftrightarrow$ parents $\leftrightarrow$ teachers. When working according to this model, the acquisition of the traditional culture is a well-justified, purposefully planned acquisition of the culture in action, when at the same time each person involved in the acquisition of the traditional culture searches responses to his own life experience, knowledge, and interest (Valbis, 2005).

Getting to know the traditional culture is both the process and the result directed at understanding experience of self, other person and the world. The traditional culture is an objective phenomenon. Its diversity, wholeness, distribution, ability to repeat is a material for subjective 
experience therefore learning of traditional culture should be seen as a culture phenomenon which reflects the man's real life in a concentrated and direct manner and serves as universal therapeutic metaphor, and is a source for man's self-cognition and self-assertion. Any form of expression of the traditional culture includes experience which is simultaneously particular for all people and the specific ethnos, it hides an enormous force which integrates all energy of its creators - the previous generations, and is being renewed and recreated repeating each time anew because the traditional culture texts recited over the centuries have concentrated the collective human experience and the separate voice of each nation (Jungs, 1994).

Life of each individual contains an endless row of choices, and traditions, which are different for each nation, determine the limitations or prohibitions. Each nation thus structures its life, turning into a peculiar, inimitable, unique phenomenon (Зыкова, 2006).

Learning of ethnos' traditional culture in a unity of content and form is a long-lasting and complicated process of learning oneself and others, as a result of which the student forms a set of attitudes towards the environment, a model of behaviour which lets getting along with others, facilitates the emotional experience and it is means for inheritance of skills particular to the ethnos (traditional singing, trade and other).

Within the Latvian language studies, by acquiring the traditional culture, it is possible to show the students the unity of spiritual and material world, thus ensuring the holistic approach towards development of personality.

Since development of personality takes place in a specific social and culture-historical environment in interrelation with other people and nature, then it is important to teach the students to understand the processes in the world around, to find out their relations with the environment, culture, form their civil position and ethnic belonging, attitude towards cultural-historic heritage, be able to analyse and influence the processes dominating in the society - to become integrated in the society and ethnos' culture.

Within the first stage of the elementary education, an organization of content the Latvian language study is more suitable, which corresponds to processes in nature and which focusses on main traditional annual celebrations. Annual celebrations - winter and summer solstice, spring and autumn solstice, range of other practices related to the individual life of a person - form definite points of account within the flow of the year and are the means which structure the person's (family's, group's, class') life giving the opportunity to experience our human existence as part of the nature. Modern individual feels the time as linear phenomenon, in the form of „it was already” and „it will be”, but the modern individual still has the inner necessity for activities and rituals which provide significance to the life. The rituals which have been performed within the traditional culture since the times immemorial and which are taught to students by experiencing the annual events, are the form which includes self-realization, self-expression, experience of the world and the Divinity (Зыкова, 2006; Konsa, 2004).

Taking into account the specifics of development typical to smallest children of the school age, such pedagogical means should be used at the learning process of the Latvian language which helps the student to become an active participant, curious researcher of the traditional culture. Understanding of syncretism of the traditional culture is formed as a result of active cognition and emotional interaction, which are based on feelings - perception - concepts - thinking. Practical manifold activity of the student lets one's experience become active, expand and be useful at new situation, get positive emotions during the learning process, discover the world by the activities of searching (Anspoka, Siliṇa-Jasjukēviča, 2006; Konsa, 2004). 
Within the learning of the traditional culture, the work with the study text is of a huge importance. The text receives its meaning in context. Each transfer of the folklore text to another form - a literary, historical or cultural context, grants a new meaning. The folklore texts due to their dynamic character have many meanings; each repeated usage brings also its previous contexts as part of the entirety of its countless meanings. Thereby the teacher becomes aware of his responsibility in the process of acquiring the traditional culture and safeguarding it. Within the pedagogical process, the acquisition of the folklore text is not only an intellectual activity, it should be related to activity - game, singing of songs, dancing, performance of rituals, practices, which take place in definite circumstances, context of students' life or season, learning or celebration situation, the theme to be reviewed.

Holistic approach to the text is a very significant part of pedagogy of traditional culture. Mythical or the syncretic thinking of the ancestors balanced the reality with its symbolic expression finding its reflection in the folklore texts. In the course of time, as the thinking, language developed, the development of the symbol was lost to the reality; however, at the level of the collective subconsciousness the symbols are still active. By the folklore text they continue to approach each listener. At the moment when a traditional culture formula is performed in a definite situation which is suitable for it (song ritual, dance, game, proverb, saying and the like), the person likewise reveals the voice of humanity and becomes its creator because it manages this universal voice which included the universal values, and the person's self-expression takes place in action, enforcing his will, wish, ability and understanding (Оленкин, 2005; Konsa, 2004).

During the acquisition of the text at the initial stage, the attention should be drawn to explanation of less-heard words so that the meaning of the text was freely perceived and understood. In the wider meaning by the help of fairy-tale, tale, legend language, a diverse, purposeful process of acquiring variants for solving metaphors, meanings, models of behaviours, conflicts is revealed. Any trial to understand the folklore text is a trial to analyse its semantic and hidden meaning (Зыкова, 2006).

A significant place in content of the Latvian language study should be showed to texts of narration folklore because the plot of the narration folklore being so rich of characters, gives the student many revelations in an understandable language regarding his own self and the environment in total. "This experience is not at all to be related with the child's experience of the objective reality acquired during this life, namely, it is not an individual set of associations acquired in this life provoking only feelings related to associations. The tales address the listener by the help of extrapersonal, divine - this language is born outside the individual experience and included the collective feeling which has come into being long before people learnt to communicate in the language of mind. These feelings then form the human soul and, when a person is born, this soul comes with him prior to having accumulated any other experience." (Kālis, 2006, 44).

When working with the youngest children of the school age, there is no meaning and it is even harmful to explain the figurative expression of tales. It is important to let the child life the text as an image - learn and feel the characters' actions, mutual attitudes, and way of solving problems. The teacher should certainly know the symbolical language, semantic levels, tale's metaphor. Only then the pedagogical work will be valuable. Knowledge of the text's symbolic language, sense and meaning is available to the teacher at studies of folklore, philosophy, mythology, anthropology, history, linguistics and religious conception of ethnos. This knowledge develops the ability to see the hidden meaning of the narrative behind the only seemingly childish content. In turn, a creative pedagogic environment for using diverse ways to stipulate the student's learning activities applies the true tasks of learning, upbringing and developing the student's personality within the correlation of acquiring the traditional culture. 
There are several objective factors which make the acquisition of content of the traditional culture easy or vice versa - makes it complicated. The place, cultural environment of the definite educational institution, where the student is located, plays an undeniably significant role. Urban children's and rural children's experience on natural processes, concept of differences of economical life in town-environment and in the country-side is distinct. Urban children have fewer possibilities to feel the nature's close influence on human life. At the same time the urban child has other advantages (possibility to visit museums, exhibitions, use electronic resources and the like). It depends on the teacher's professionalism, how purposefully he evaluates the respective cultural environment and uses the given possibilities for development of the student's socio-cultural competencies. The student can learn his own and other ethnos' culture in a more successful and deep manner, and to form a positive attitude towards it if the teacher understands and is able to use the "language" of the traditional culture - musical, choreographic, "language" of objects in their mutual unity - within the pedagogical process (Зыкова, 2006). This means that for the teacher of the Latvian language, a need arises not only to know traditions of various ethnoses (in the latest years, it is extremely important because schools with the Latvian language as the teaching language have turned into multi-ethnic schools from mono-ethnic ones), but also to be able to reveal them together with the students verbally, by a song, dance and help of other movements. Development of the student's socio-cultural competence takes place not only in social and culture-historical environment, but also in contacts with other people and nature. In a personally important work, it is easier to acquire language user's experience in correlations and to understand what is going on in the world around, to form relations with the environment, its culture, form the civil position and maintain the ethnic belonging, positive attitude towards culture-historical heritage, to be able to analyse and influence the processes taking place in the society, to integrate in the multicultural society and the ethnos' culture of one's own.

\section{Conclusions}

- Latvian culture-educational politics mark the importance of learning the traditional culture as a whole but the educational programs do not specify the issues of content of the traditional culture, leaving the subjective interpretation for the teachers.

- Since the folklore has not been included as a separate subject in the first stage of elementary education, it is regarded as one of most important aspects of the content of the Latvian language study. In the teaching tools for acquisition of the Latvian language too often show the content of folklore only in examples existing outside the context as a set of exercises and tasks which do not create a concept of syncretism of the traditional culture. It is important that the student not only perceives the information included in a word as the basic element of the language, in a sentence and text regarding ethnos' view of the world, traditions, practices, their differences and common traits in various regions, cultures of different ethnoses, but also gets a personal inner feeling and the acquired content becomes a value to his life.

- For the student to acquire the folklore content form the teaching aids not only as the retrospection of the past at work with the folklore texts, such methodological tools and learning organisation forms should be included, which require his cooperation, contacts with others, need to analyse the acquired experience, self-assess and valuate it.

- A topical need of professional teachers of the Latvian language at work with students is to acquire knowledge on traditional cultures of various ethnoses, improve the skills to see it in an entirety together with development tendencies of modern society.

- If we wish that each student would get involved in the process of acquiring, safeguarding and further developing of the traditional culture, the study programs for teachers at institutions of 
higher education should turn more attention to the content of study courses, which are meant for acquisition of the traditional cultures of various ethnoses and their teaching methods.

- The research work in the field of pedagogy of the traditional culture should be emphasised in order to promote methodology, which would be scientifically grounded for acquisition of the traditional culture among different age groups because the Latvian system of education has not sufficiently evaluated the positive influence of acquiring the traditional culture to the formation of the student's value system.

\section{REFERENCES}

1. Anspoka Z., Siliņa-Jasjukeviča G. (2006) Latviešu valoda mazākumtautību skolēniem latviešu mācībvalodas sākumskolā. Riga: Lielvārds, 80 lpp.

2. Bula D. (2000) Dziedātājtauta. Folklora un nacionālā ideologija. Rīga: Zinātne, 186 lpp.

3. Jungs K. G. (1994) Dvēseles pasaule. Rīga: Spektrs, 216 lpp.

4. Kālis E. (2006) Brīnumpasaka - dvēseles valoda. Psihologija mums, Nr. 2, 44.-50. lpp.

5. Konsa K. (2004) Holistic Approach to Cultural Heritage: Educational Perspective. Journal of Teacher Education Training, Vol. 4, p. 19-24.

6. Kursīte J. (1996) Latviešu folklora mìtu spogulī. Rīga: Zinātne, 434 lpp.

7. Meistere B. (2000) Folkloras interpretācija skolas mācību grāmatās padomju periodā. Materiāli par Latvijas kultūrvidi: fakti un uztvere. Rīga: Zinātne, 34.-43. lpp.

8. Ozoliņš G. (2006) Latviešu tautasdziesmu totēmiskā simbolika (radību, krustību un kāzu rituāli). Summary of the promotion paper. Daugavpils: University of Daugavpils, $15 \mathrm{p}$.

9. UNESCO Convention for the Safeguarding of Intangible Cultural Heritage (2006) Riga: UNESCO Latvian National Commission, $16 \mathrm{p}$.

10. Valbis J. (2005) Skolēna personības attīstība - izglìtības virsuzdevums. Rīga: Zvaigzne ABC, 200 lpp.

11. State Standart of Elementary Education. www.izm.gov.lv (12.12.2007)

12. Guidelines for State Culture-Politics for years 2006-2015. National State. (2006) Rīga: Ministry of Culture of the Republic of Latvia, $104 \mathrm{p}$.

13. Оленкин С. (2005) Фольклор и школа. htpp: www.pjatnica.com/content/view/87/25/ (12.12.2007)

14. Оленкин С. (1996) Фольклорная педагогика в начальной школе с русским языком обучения. http: www.pjatnica.com/content/view/53/25/ (12.12.2007)

15. Зыкова М. Н. (2006) Фольклоротерапия: структурирование жизни через обряд. Москва: Издательство Московского психолого-социального института, с. 77.

Professor Dr. paed. Zenta Anspoka

Riga Teacher Training and Educational Management Academy

Address: Imantas 7. līnija, Riga, LV-1083, Latvia

Phone: +37167808136

Fax: +37167808034

E-mail: zenta.anspoka@rpiva.lv

\section{Lecturer Mg. paed. Gunta Siliṇa-Jasjukeviča}

Riga Teacher Training and Educational Management Academy

Address: Imantas 7. linija, Riga, LV-1083, Latvia

Phone: +37167808136

Fax: +37167808034

E-mail: gunta30@tvnet.lv 